\title{
Histomorphological and microanatomical characteristics of the olfactory organ of freshwater carp, Cirrhinus reba (Hamilton)
}

\author{
Saroj Kumar Ghosh, Padmanabha Chakrabarti
}

Received - 01 July 2016/Accepted - 22 September 2016. Published online: 31 December 2016; $\odot$ Inland Fisheries Institute in Olsztyn, Poland Citation: Ghosh S.K., Chakrabarti P. 2016 - Histomorphological and microanatomical characteristics of the olfactory organ of freshwater carp, Cirrhinus reba (Hamilton) - Arch. Pol. Fish. 24: 201-208.

\begin{abstract}
The morphoanatomy, cellular organization, and surface architecture of the olfactory apparatus in Cirrhinus reba (Hamilton) is described using light and scanning electron microscopy. The oval shaped olfactory rosette contained $32 \pm$ 2 primary lamellae on each side of the median raphe, and was lodged on the floor of the olfactory chamber. The olfactory lamellae were basically flat and compactly arranged in the rosette. The olfactory chamber communicated to the outside aquatic environment through inlet and outlet apertures with a conspicuous nasal flap in between. The mid dorsal portion of the olfactory lamellae was characterized by a linguiform process. Sensory and non-sensory regions were distributed separately on each lamella. The sensory epithelium occupied the apical part including the linguiform process, whereas the resting part of the lamella was covered with non-sensory epithelium. The sensory epithelium comprised both ciliated and microvillous receptor cells distinguished by the architecture on their apical part. The non-sensory epithelium possessed mucous cells, labyrinth cells, and stratified epithelial cells with distinctive microridges. The functional importance of the different cells lining the olfactory mucosa was correlated with the ecological habits of the fish examined.
\end{abstract}

\footnotetext{
S.K. Ghosh [־]

Department of Zoology

Bejoy Narayan Mahavidyalaya, Itachuna

Hooghly-712 147, West Bengal, India

e-mail: saroj.fisherylab@gmail.com

P. Chakrabarti

Fisheries Laboratory, Department of Zoology

The University of Burdwan, Golapbag

Burdwan-713 104, West Bengal, India
}

Keywords: Cirrhinus reba, olfactory apparatus, anatomy, histology, fine structure

\section{Introduction}

The olfactory organ is a chemoreceptor organ which perceives chemical signals and is involved in diverse teleost behaviors (Hara and Zielinski 1989). Olfaction is of utmost significance in fish, and it participates in essential life processes such as feeding, alarm situations, migration, mother-young recognition, and sexual behaviors (Camacho et al. 2010). The olfactory organ is outwardly sheathed with olfactosensory epithelium which performs a significant role in olfaction (Hara 1971). Olfactory cues are detected by the receptor neurons lining the olfactory epithelium that are stimulated when they come into contact with certain chemicals in the water, and they relay olfactory information to the brain (Lara 2008).

Smell is one of the senses that drive basic patterns of behavior in teleosts, where life is confined to the aquatic environment. The olfactory organs of fish are widely diversified depending on systematic groups and ecological habitats (Zeiske et al. 2009). The structure and function of the fish olfactory organs have been investigated by a number of researchers using light and electron microscopes

(C) Copyright by Stanisław Sakowicz Inland Fisheries Institute in Olsztyn.

(C) 2016 Author(s). This is an open access article licensed under the Creative Commons Attribution-NonCommercial-NoDerivs License (http://creativecommons.org/licenses/by-nc-nd/3.0/). 
(Bhute and Baile 2007, Ghosh and Chakrabarti 2009, Ma and Wang 2010, Atta 2013, Patle and Baile 2014, Ghosh et al. 2015, Samajdar and Mandal 2016). Studies show there is immense diversity regarding shape, the number and position of olfactory lamellae, the distribution of sensory and non-sensory epithelium, and the abundance of various receptor cell types in several teleosts depending on their adaptation to different behavoirs and habitats. Reports are also available on the morphohistological peculiarities of the olfactory organs of cyprinidae (Ojha and Kapoor 1973, Bhute and Baile 2007, Ghosh and Chakrabarti 2013, 2014, 2015, Samajdar and Mandal 2016). The oval and multi-lamellar olfactory rosette of cyprinids are characterized by linguiform processes that belong to the group of "eye-nose fishes." However, very little information is available relating to the cellular organization of the olfactory epithelium and the functional significance in olfaction. The aim of the present study was to describe the detailed structure of the olfactory organ in an omnivorous, bottom-feeding teleost, Cirrhinus reba (Cypriniformes, Cyprinidae) using light and scanning electron microscopy.

\section{Materials and methods}

\section{Tissue collection}

Ten specimens of C. reba (15 to $17 \mathrm{~cm}$ in length) were obtained from the Regional Research Centre of the Central Institute of Freshwater Aquaculture, Kalyani Field Station (2258’60 N, 88²8’60 E), West Bengal, India. The fish were anesthetized in 3\% urethane (Sigma-Aldrich Chemicals Company, City of Kempton Park, South Africa) and sacrificed following the guidelines of the institutional animal ethical committee. The olfactory rosettes were dissected out under a Zeiss Stemi 2000-C (Oberkochen, Germany) stereoscopic binocular microscope and the number of lamellae was counted. The olfactory organs were processed further for the histological and scanning electron microscopy studies.

\section{Light microscopy (LM) investigation}

Olfactory tissues were kept in aqueous Bouin's fixative for a period of 16-18 h. After that the tissues were washed repeatedly in $70 \%$ ethanol to remove picric acid, dehydrated through graded series of ethanol, and cleared with xylene. The tissues were infiltrated in paraffin wax of $56-58^{\circ} \mathrm{C}$ (Merck, Darmstadt, Germany) under a thermostat vacuum paraffin embedding bath for $1 \mathrm{~h}$. Serial paraffin sections were cut in $4 \mu \mathrm{m}$ thicknesses using a rotary microtome (Weswox MT-1090A, Ambala, India). After routine histological processing, deparaffinized sections were stained with Delafield's Hematoxylin-Eosin (HE) and Mallory's triple (MT) stain (Mallory 1936). The staining slides were mounted with DPX, viewed and photographed under an Olympus-Tokyo PM-6 compound microscope using Kodak Professional T-Max 100 Film (Black and White: $24 \times 36 \mathrm{~mm}$ ).

\section{Scanning electron microscopy (SEM) investigation}

After dissecting the olfactory chamber, the olfactory rosettes were perfused in vivo with a $2.5 \%$ glutaraldehyde solution in a $0.1 \mathrm{M}$ phosphate buffer ( $\mathrm{pH}$ 7.4) for $20 \mathrm{~min}$. Then the olfactory rosettes were carefully dissected and washed repeatedly in $1 \%$ Tween 40 solutions. Tissues were fixed in $2.5 \%$ glutaraldehyde for $24 \mathrm{~h}$ at $4^{\circ} \mathrm{C}$ and post fixed with $1 \%$ osmium tetroxide $\left(\mathrm{OsO}_{4}\right)$ in $0.1 \mathrm{M}$ phosphate buffer ( $\mathrm{pH}$ 7.4) for $2 \mathrm{~h}$ at room temperature. Fixed tissues were rinsed thoroughly in the same buffer and dehydrated through ascending series of acetone followed by isoamyl acetate. The tissues were dried with a critical point drier (Hitachi 8CP2), mounted on metal stubs, coated with gold palladium (20 nm thick), and examined under a Hitachi S-530 scanning electron microscope. 


\section{Results}

\section{Morphoanatomy}

C. reba (Fig. 1A) possesses a pair of olfactory chambers located on the dorsolateral sides of the snout in front of the eyes (Fig. 1B). Each olfactory chamber is marked externally by two separate openings; an anterior inlet and a posterior outlet. These nasal openings are placed close to each other and distinguished by visibly directed membranous nasal flap. The anterior one is almost oval in shape and persists as a spacious opening, while the posterior one is crescent shaped and wrapped with the nasal flap (Fig. 1C). The olfactory organ is lodged in the ethmoid re-

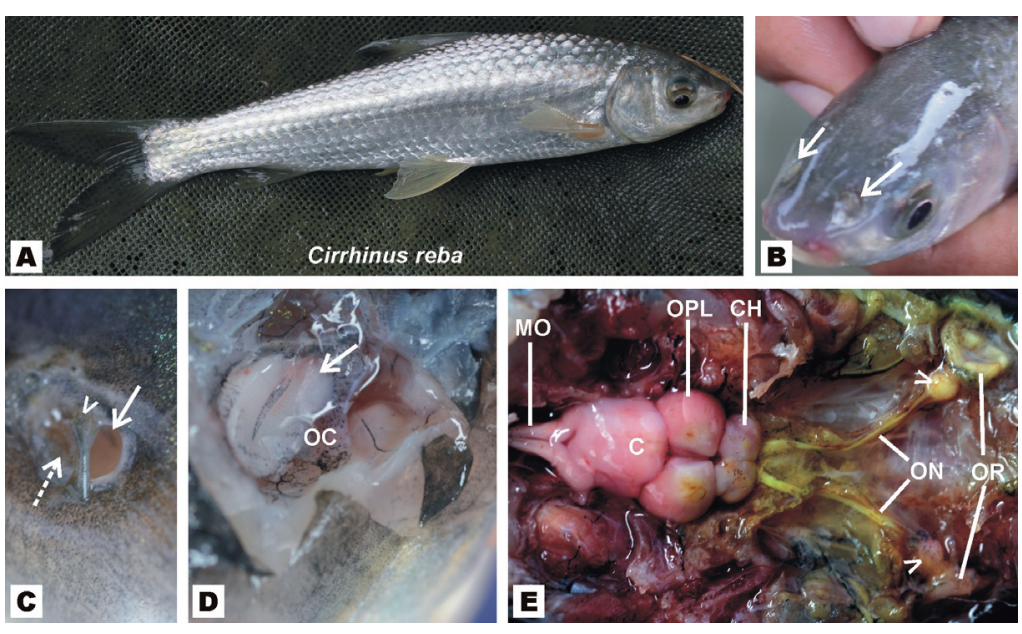

Figure 1. Photographs showing the position of the nostrils, olfactory rosette, and the connection of the olfactory organ with the brain in C. reba. (A) Entire structure of the whole fish, Cirrhinus reba; (B) Dorsal-lateral side of the head showing the nostrils (solid arrows). (C) Anterior inlet (solid arrow) and posterior outlet (broken arrow) distinguished by the nasal flap (arrow head). (D) Olfactory organ (arrow) located on the floor of the olfactory chamber (OC). (E) Dissected portion of head showing the olfactory system comprising the olfactory rosette (OR), olfactory bulbs (arrow heads), and olfactory nerves $(\mathrm{ON})$ attached to the cerebral hemisphere $(\mathrm{CH})$. OPL represents the optic lobe, $\mathrm{C}$ - the cerebellum, and MO - the medulla oblongata. gion of the head at the bottom of the olfactory chamber (Fig. 1D). Olfactory rosettes along with swelling olfactory bulbs are conjoined to the cerebral hemisphere of the brain by narrow olfactory nerves (Fig. 1E).

\section{Cellular organization}

The olfactory rosette is nearly oval shaped with a convex ventral and a concave dorsal surface, and it occupies most of the space of the olfactory chamber (Fig. $2 \mathrm{~A})$. The rosette consists of a series of $32 \pm 2$ primary lamellae on the left and right sides of the median raphe. The lamellae are closely set and originate from the raphe. The interlamellar space in between adjoining lamellae is narrow. The raphe comprises a central axis on which the lamellae rest. The smallest lamellae are located at both ends while the longer ones are placed medially. They adhere to the wall of the olfactory chamber by their ventral edges and to the raphe by their proximal terminates. Olfactory lamellae are marked by sensory and non-sensory epithelium. The non-sensory epithelium is distributed irregularly, while the sensory epithelium contains a tuft of receptor cells (Fig. 2B). The middle dorsal portion of each lamella bears a flat linguiform process (Fig. 1A). The sensory epithelium mainly holds onto the apical part and the middle linguiform process, while the resting parts of the lamellae are veiled with non-sensory regions.

Histologically, the olfactory epithelium is a continuous thick sheet of stratified epithelial cells that folds to form lamellae. The central core of the lamella is lined on either side by the olfactory epithelium. It is composed of connective tissue with nerve fibers and blood vessel (Figs. 1C, D and E). The lamellae are characterized by mixed sensory and non-sensory epithelium that have special cells in each area (Fig. 2E). A well-developed basement membrane is usually distinguishable which separates the olfactory epithelium from the central core region (Fig. 2D). The sensory epithelium is lined by a large number of ciliated receptor cells and microvillous cells, whereas the non-sensory epithelium consists of mainly stratified epithelial cells, mucous cells, and labyrinth cells (Fig. 2E).

Receptor cells are differentiated by darkly stained oval or elongated nuclei situated deep in the epithelium. These are elongated sensory elements of 


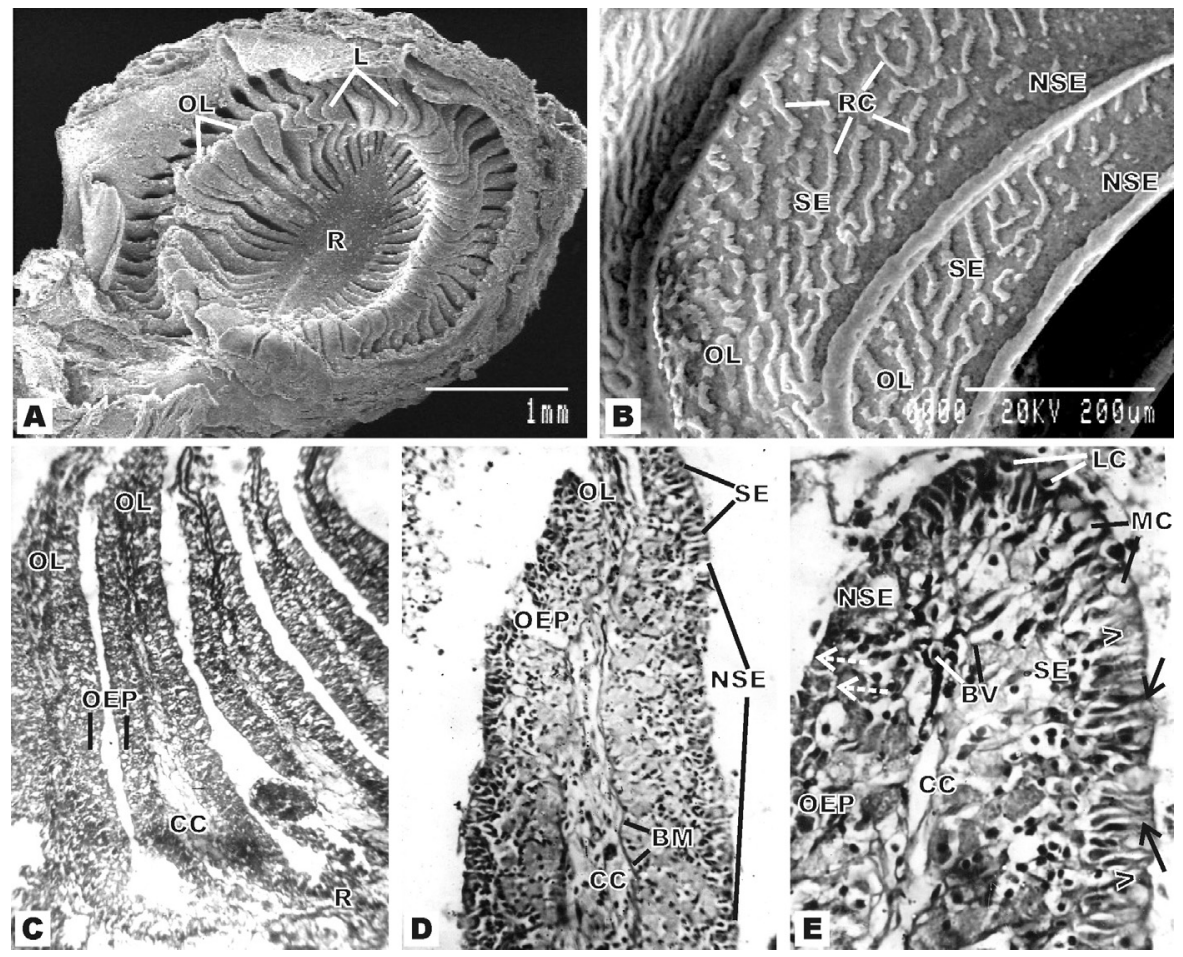

Figure 2. Photomicrographs of the olfactory epithelium of C. reba by scanning electron microscopy (SEM) and light microscopy stained with Delafield's Hematoxylin-Eosin (HE). (A) Oval shaped olfactory rosette exhibits the olfactory lamellae (OL) radiating from the central median raphe (R). Note the presence of flat linguiform processes (L) of OL (SEM) at 50x magnification. (B) Olfactory lamellae (OL) showing the distribution of non-sensory epithelium (NSE) and sensory epithelium (SE) with a cluster of ciliated receptor cells (RC) (SEM) at 600x magnification. (C) Section of olfactory lamellae (OL) radiated from the raphe (R) showing the olfactory epithelium (OEP) separated by the central core (CC) (HE) at 100x magnification. (D) Olfactory lamellae (OL) contains sensory (SE) and non-sensory (NSE) epithelium (OEP) separated from the central core (CC) by the basement membrane (BM) (HE) at 200x magnification. (E) Olfactory epithelium (OEP) with the sensory area (SE) lined with both ciliated (solid arrows) and microvillous receptor cells (arrow heads). Non-sensory area (NSE) with mucous cells (MC), labyrinth cells (LC), and stratified epithelial cells (broken arrows). Note the presence of blood vessels (BV) in the central core (CC) (HE) at 400x magnification.

the olfactory epithelium that are mainly distributed in the proximal region of the epithelium (Figs. 2E and 3A). The dendrite of primary receptor cells runs as a narrow cylindrical process up to the epithelial surface where it enlarges into a small knob-like structure (Fig. 3A). The secondary receptor cells mainly present below the primary receptor cells. In some areas the axonal end of the primary neuron synapses with the dendrite tips of the secondary neurons. Microvillous cells are confined to the surface zone of the olfactory epithelium and bear faintly visible cilia. The nuclei of these cells are small and lightly stained (Fig. 3A). Under SEM, the surface of the sensory epithelium contains a dense population of ciliated receptor cells and scattered microvillous cells (Fig. 3B). They arise together, but the ciliated receptor cells predominate over microvillous cells. The dendrite process of the ciliated receptor extends as a flagellated process. The microvillous cells have no cilia and are dispersed among ciliated receptor cells along the free surface of the epithelium presenting a sculptured appearance.

Histologically, the non-sensory epithelium is composed of stratified epithelial cells, mucous cells, and labyrinth cells. Stratified epithelial cells are found all over the epithelium and provide the basic structure of the lamella. These cells are elliptical to columnar in shape with conspicuous basophilic nuclei and less granular cytoplasm (Fig. 4A). Mucous cells are large in number and located in the superior layer of the olfactory epithelium. They are rounded or ovoid, and they secrete mucins. The oval labyrinth 


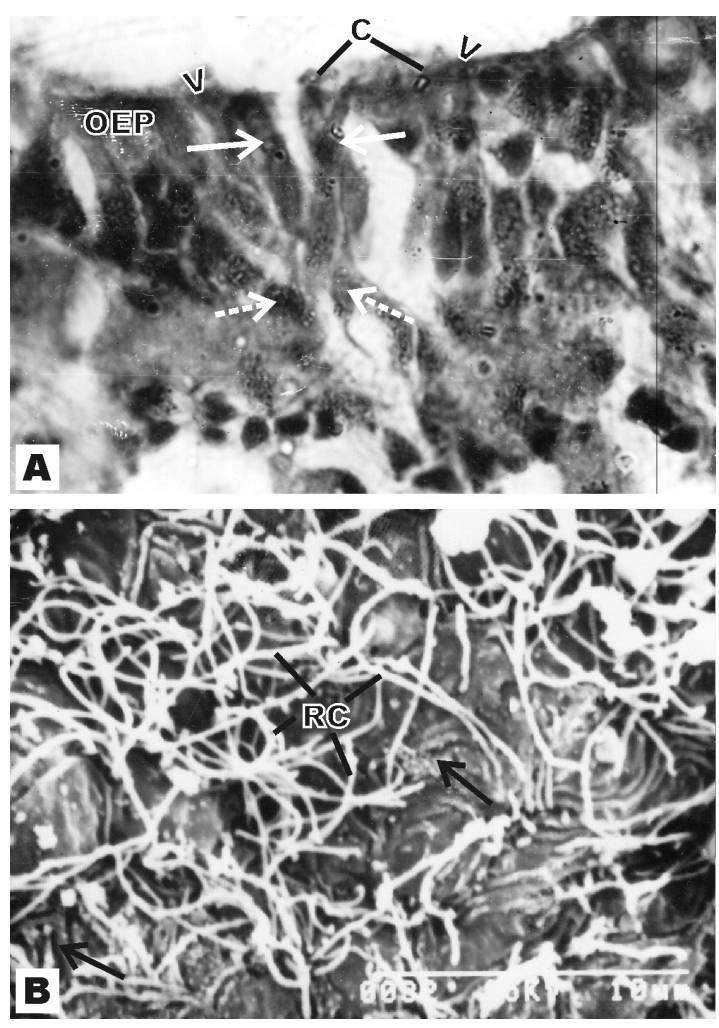

Figure 3. Photomicrographs of the scanning electron microscopy (SEM) and histological sections of olfactory tissues of C. reba stained with Mallory's triple (MT) stain. (A) Section of sensory olfactory epithelium (OEP) shows the position of primary receptor cells (solid arrows), secondary receptor cells (broken arrows), and dispersed microvillous cells (arrow heads). Note the presence of the knob-like structures (C) of receptor cells on the epithelial surface (MT) at 1000x magnification. (B) Sensory epithelium provided with dendrite patches of ciliated receptor cells (RC) and microvillous cells (solid arrows) (SEM) at 5000x magnification.

cells are situated on the epithelial surface with conspicuous nuclei toward the basal portions. Basal cells are small, almost round, with a prominent nucleus, and are scattered in the deeper part of the epithelium (Fig. 4A). SEM study reveals the surface of non-sensory epithelium has a few dissipated receptor cells in between polygonal stratified epithelial cells bearing labyrinth patterned microridges (Fig. 4B). The labyrinth cells are of peculiar structure and clustered among stratified epithelial cells in some areas of the non-sensory epithelium. They are almost ovoid with pock marks on their apical surface (Fig. 4C). The openings of mucous cells are observed throughout the epithelial surface. The raphe is characterized by

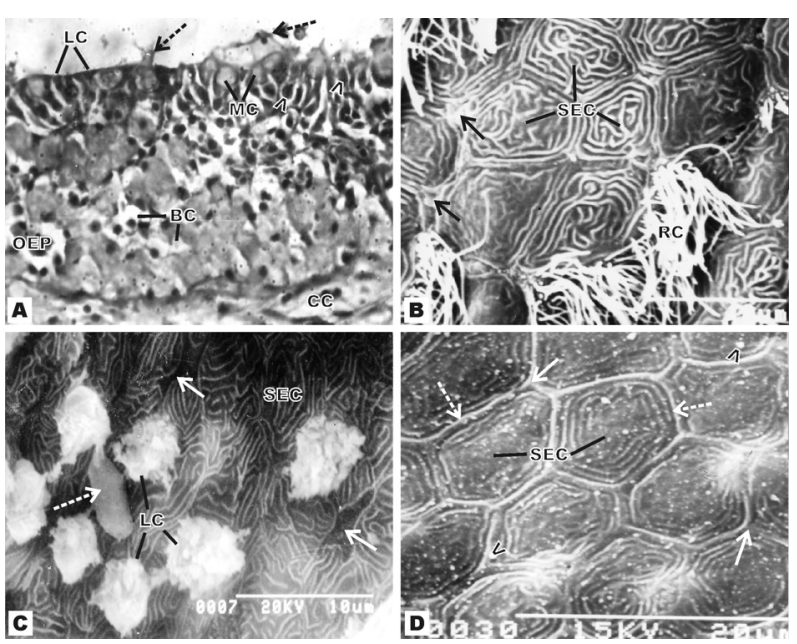

Figure 4. Photomicrographs of the olfactory epithelium of C. reba by scanning electron microscopy (SEM) and histological sections stained with Delafield's Hematoxylin-Eosin (HE). (A) Section of non-sensory olfactory epithelium (OEP) comprises a series of mucous cells (MC) with secreted mucin (broken arrows), stratified epithelial cells (arrow heads), and Labyrinth cells (LC). Note the presence of basal cells (BC) above the central core (CC) (HE) at 400x magnification. (B) A few scattered ciliated receptor cells (RC) in between stratified epithelial cells (SEC). Note the presence of mucous cells (solid arrows) in between SEC (SEM) at 4500x magnification. (C) Surface feature of non-sensory epithelium shows closely arranged stratified epithelial cells (SEC) and a cluster of labyrinth cells (LC). Note the opening of mucous cells (solid arrows) in between SEC and blood cells (broken arrow) (SEM) at 4000x magnification. (D) Topological view of the raphe represented by the precise ordering of stratified epithelial cells (SEC) and the opening of mucous cells (solid arrows). Note the presence of mucin droplets (arrow heads) on SEC. Broken arrows indicate the double ridged structure in between SEC (SEM) at 4000x magnification.

the presence of complex microridges on the surface of epithelial cells and joined to the adjacent cells forming a double ridged structure (Fig. 4D). Secreted mucins from mucous cells are associated with the microridges of the stratified epithelial cells.

\section{Discussion}

Fishes have good senses of smell, and are adept at discerning odors with the help of a pair of olfactory organs connected to the olfactory lobes of the brain through the olfactory nerves (Singh 1977). The olfactory chamber of C. reba is connected to the external aquatic environment through two separate nasal 
apertures - the anterior inlet and the posterior outlet. The flow of water is unidirectional, and it enters the olfactory chamber through the anterior opening and leaves through the posterior after bathing the olfactory mucosa. Two nasal openings are placed close to one another, detached by an outwardly, forwardly directed nasal flap. This nasal flap provides mechanical assistance to deflect water flow into the inlet nostrils and to prevent it from gaining access into the posterior outlet (Ojha and Kappor 1973, Ghosh and Chakrabarti 2013). According to Burne (1909), the crescent-shaped posterior outlet is highly specific to carp, but this seems to be too sweeping a statement. Suitable ventilation of the olfactory chamber is needed to bring the odorants to the olfactory mucosa so they can perceive chemical signals from the aquatic ecosystem (Balanger et al. 2003).

The present study reveals that the olfactory rosette of $C$. reba is more or less oval and can be grouped under Bateson's (1889) rosette type 3 or Burne's (1909) rosette column I. Further, according to Teichmann (1954), the oval type of olfactory organ is classified as group I, or the "eye-nose fishes," which means the olfactory organs and eyes are equally developed. The olfactory mucosa of C. reba folds to form $32 \pm 2$ primary lamellae on both sides of the central raphe and are optimally adapted to provide a large surface area in this limited space. The lamellae are the functional part of the olfactory system, and the number of lamellae is related to functional capacity (Wunder 1957, Ma and Wang 2010). The median depression on the olfactory rosette that stems from the radial arrangement of the lamellae enhances water retention time as well as the interaction time of odorant molecules with the receptor cells (Samajdar and Mandal 2016). The distribution of the sensory and non-sensory epithelia on the surface of the lamellae is evidence of the great variation among teleosts that permits them to adapt to specific environments (Yamamoto 1982). The ecological niche inhabited by a given species has an immense impact on the cellular organization of the olfactory epithelium (Hara 1994). The mid-dorsal edges of the lamellae are characterized with linguiform processes which slow water flow over the olfactory mucosa and facilitate better interaction between odorant particles and receptor cells (Ghosh and Chakrabarti 2014).

It is well established that the receptor cells in the olfactory epithelium participate in the olfactory transduction mechanism and are stimulated by odor-bearing substances, and also that they enable the fish to detect food. Buck and Axel (1991) report that olfactory processing commences at the apical tip of the receptor cells. Hino et al. (2009) conclude that fish can judge and detect water-soluble chemicals through sensory receptor cells during water ventilation over the olfactory mucosa. In the present investigation, the long, well-developed dendrite process of the receptor cells enables the fish to smell its food and is mobilized by different olfactory cues in the aquatic ecosystem. The synaptic connection between the primary and secondary receptor cells could extend from the epithelial surface to the central core. Goel (1978) also observed secondary neurons in the olfactory epithelium of Notopterus notopterus (Pall.). Graziadei and Metcalf (1971) postulate that new neurons replace old, degenerating ones and establish fresh synaptic contact in the olfactory bulb. In contrast to the ciliated receptor cells, the microvillous receptor cells consist of minute dendrites, which have also been observed by Camacho et al. (2010) in the olfactory epithelium of sturgeon. Bhute and Baile (2007) reported that the microvillous receptor cells perceive and process pheromone signals, which is an important breeding stage in Labeo rohita (Hamilton). Waryani et al. (2013) conclude that the microvillous cells in the olfactory epithelium of cave fish, Sinocyclocheilus jii Zhang \& Dai play a significant role in reproduction. Zippel et al. (1997) report that there are ciliated and microvillous receptor cells in the olfactory epithelium of gold fish. They suggest that microvillous receptor cells mediate responses to pheromones whereas ciliated cells mediate responses to amino acids.

Stratified epithelial cells are believed to provide mechanical support to the other sensory cells of the olfactory epithelium. The apical surface of stratified epithelial cells in the non-sensory epithelium and 
raphe are embossed with microridges which help hold the mucous film over the epithelium and protect the surface from mechanical as well as chemical injury (Chakrabarti and Ghosh 2011). The labyrinth cells on the surface of the epithelium could serve as excretory cells for osmoregulation and ion regulation. In this way, they could facilitate the optimal functioning of the olfactory organs in water of different salinities. Shirai and Utida (1970) mention that labyrinth cells could be involved in electrolyte transport because they are structurally similar to the chloride cells found in fish gills. Mucous cells secrete mucin which protects the olfactory epithelium from external hazards, and their secretions are an appropriate medium for the diffusion of odorants and they assist in the smooth flow of water during ventilation. The mucus film could also trap xenobiotics, which delays the access of heavy metals and salts to the underlying olfactory tissue (Waryani et al. 2013). The basal cells are situated in the deeper layer of the olfactory epithelium, which is believed to be the progenitor of receptor and supporting cells (Zeiske et al. 1992). Graziadei and Metcalf (1971) report that the basal cells are able to differentiate into receptor cells, while Ojha and Kapoor (1973) observed their transformation into supporting cells.

C. reba is an omnivorous bottom feeder dependent on its olfactory sense for exploring the surroundings of the aquatic ecosystem which it inhabits. The dense aggregation of ciliated receptor cells in the olfactory epithelium is of special interest as it enables the fish to detect food and perceive most chemical signals. The presence of microvillous cells perform a significant role in regulating reproduction. The microridges of the stratified epithelial cells assist in holding mucus film over the epithelial surface and protecting it from external hazards. Further electron microscopy and immunohistochemical studies on the olfactory epithelium of C. reba are recommended to identify the cellular components and their proper functional significance. Olfaction in fishes is both aquatic and chemical. With the growing interest in aquaculture, the role of olfactory organs in detecting heavy metals has an important practical aspect.
Acknowledgments. The authors are grateful to Dr. S. Chakraborty, former Scientist-in-Charge, University Science Instrumentation Centre, University of Burdwan, for his technical support in SEM analysis and also to Dr. P. P. Chakrabarti, Scientist-in-Charge, Regional Research Centre of ICAR-Central Institute of Freshwater Aquaculture, Kalyani Field Station, Santalpara, for providing the fish specimens.

Author contributions. P.C. supervised and S.K.G. conducted the research; S.K.G wrote and P.C. edited the manuscript.

\section{References}

Atta K.I. 2013 - Morphological, anatomical and histological studies on the olfactory organs and eyes of teleost fish: Anguilla anguilla in relation to its feeding habits - J. Basic Appl. Zool. 66: 101-108.

Bateson W. 1889 - The sense organs and perceptions of fishes, with remarks on the supply of bait - J. Mar. Biol. Assoc. 1: 225-256.

Belanger R.M., Smith C.M., Corkum L.D., Zielinski B.S. 2003 - Morphology and histochemistry of the peripheral olfactory organ in the round goby, Neogobius melanostomus (Teleostei: Gobiidae) - J. Morphol. 257: 62-71.

Bhute Y.V., Baile V.V. 2007 - Organization of the olfactory system of the Indian Major Carp Labeo rohita (Hamilton): a scanning and transmission electron microscopic study - J. Evol. Biochem. Physiol. 43: 342-349.

Buck L., Axel R. 1991 - A novel multigene family may encode odorant receptors: a molecular basis for odor recognition - Cell 65: 175-187.

Burne R.H. 1909 - The anatomy of the olfactory organ of teleostean fishes - Proc. Zool. Soc. 2: 610-663.

Camacho S., Ostos-Garrido M.V., Domezain A., Carmona R. 2010 - Study of the olfactory epithelium in the developing sturgeon characterization of the crypt cells - Chem. Senses. 35: 147-156.

Chakrabarti P., Ghosh S.K. 2011 - Histological and ultrastructural studies of the olfactory rosette of spotted butter fish Scatophagus argus (Linnaeus) - Folia Morphol. 70: 74-79.

Ghosh S.K., Chakrabarti P. 2009 - Cellular architecture and functional aspects of the olfactory rosette of Wallago attu (Bleeker) - Turk. J. Fish. Aquat. Sci. 9: 187-190.

Ghosh S.K., Chakrabarti P. 2013 - Studies on the morphology of the olfactory organ in the freshwater teleost, Labeo bata (Hamilton) - Mesopot. J. Mar. Sci. 28: 163-174. 
Ghosh S.K., Chakrabarti P. 2014 - Structural characterization of the olfactory epithelium of freshwater olive barb, Puntius sarana (Hamilton, 1822) - Int. J. Aquat. Biol. 2: 147-154.

Ghosh S.K., Pan B., Chakrabarti P. 2015 - Histoarchitectural and surface ultrastructural analysis of the olfactory epithelium of Puntius ticto (Hamilton, 1822) - Int. J. Aquat. Biol. 3: 236-244.

Goel H.R. 1978 - The structure and functions of the olfactory organs in the freshwater teleost Notopterus notopterus (Ham) - Folia Morphol. 26: 392-397.

Graziadei P.P.C., Metcalf J.F. 1971 - Autoradiographic and ultrastructural observations on the frog's olfactory mucosa - Z. Zellforsch. 116: 305-318.

Hara T.J. 1971 - Chemoreception - In: Fish physiology (Eds) W.S. Hoar, D.J. Randall, Academic Press, New York: 79-120.

Hara T.J. 1994 - The diversity of chemical stimulation in fish olfaction and gestation - Rev. Fish Biol. Fish. 4: 1-35.

Hara T.J., Zielinski B. 1989 - Structural and functional development of the olfactory organ in teleosts - Trans. Am. Fish. Soc. 118: 183-194.

Hino H., Miles N.G., Bandoh H., Ueda H. 2009 - Molecular biological research on olfactory chemorecption in fishes J. Fish Biol. 75: 945-959.

Lara M.R. 2008 - Development of the nasal olfactory organs in the larvae, settlement-stages and some adults of 14 species of Caribbean reef fishes (Labridae, Scaridae, Pomacentridae) - Mar. Biol. 154: 51-64.

Ma A.J., Wang X.A. 2010 - Functional morphology of the olfactory organ of the tongue sole, Cynoglossus semilaevis - Chin. J. Oceanol. Limnol. 28: 209-217.

Mallory F.B. 1936 - The aniline blue collagen stain - Stain Technol. 11: 101.

Ojha P.P., Kapoor A.S. 1973 - Structure and function of the olfactory apparatus in the freshwater carp, Labeo rohita (Ham. Buch.) - J. Morphol. 140: 77-85
Patle P.J., Baile V.V. 2014 - Olfactory sensory neuron morphotypes in the featherback fish, Notopterus notopterus (osteoglossiformes: notopteridae) - Ann. Neurosci. 21: 51-56.

Samajdar I., Mandal D. 2016 - Histological organization and ultrastructures of the apical surface of the olfactory epithelium of a carp, Labeo bata (Hamilton) - Int. J. Pure Appl. Zool. 4: 134-141.

Shirai N., Utida S. 1970 - Development and degeneration of the chloride cell during seawater and freshwater adaptation of the Japanese eel Anguilla japonica - Z. Zellforsch. 103: 247-264.

Singh S.P. 1977 - Functional anatomy of olfactory organs in some marine teleosts - Zool. Anz. 5B: 441-444.

Teichmann H. 1954 - Vergleichende Untersuchungen an der Nase der Fishe - Z. Morphol. Oekol. Tiere. 43: 171-212.

Waryani B., Zhao Y., Zhang C., Dai R., Abbasi A.R. 2013 Anatomical studies of the olfactory epithelium of two cave fishes Sinocyclocheilus jii and S. furcodorsalis (Cypriniformes: Cyprinidae) from China - Pak. J. Zool. 45: 1091-1101.

Wunder W. 1957 - Die Sinnesorgane der Fische - Allg. Fischereiztg. 82: 1-24.

Yamamoto M. 1982 - Comparative morphology of the peripheral olfactory organ in teleosts - In: Chemoreception in fishes (Ed.) T.J. Hara, Elsevier, Amsterdam: 39-59.

Zeiske E., Theisen B., Breucker H. 1992 - Structure, development, and evolutionary aspects of the peripheral olfactory system - In: Fish Chemoreception (Ed.) T.J. Hara, Chapman and Hall, London: 13-39.

Zeiske E., Bartsch P., Hansen, A. 2009 - Early ontogeny of the olfactory organ in a basal actinopterygian fish: Polypterus - Brain Behav. Evol. 73: 259-272.

Zippel H.P., Sorensen P.W., Hansen A. 1997 - High correlation between microvillous olfactory receptor cell abundance and sensitivity to pheromones in olfactory nerve-sectioned goldfish - J. Comp. Physiol. 180: 39-52. 